\title{
A Consideration of Japanese-Focused Organizational Behavior Research: 1981-2015
}

\author{
Lynn Godkin \\ Lamar University \\ Mikko M. Rajamāki \\ Lamar University
}

\begin{abstract}
Replicating prior work (Godkin, Endoh, \& Cahill, 1995; Godkin, Doughty, \& Hoosier, 2003), this paper juxtaposes Japan-focused organizational behavior (OB) research appearing between 2002 and 2015 with that appearing between 1981 and 2001. The purpose is to inform four questions; (1) Has there been a relative increase in the proportion of Japanese-focused papers published; (2) Has there been a relative increase in the proportion of Japanese-focused OB papers published (3) What is the nature of Japanesefocused OB papers; and (4) Are there "gaps" in the Japanese-focused OB literature? The intent is to place the 2002-2015 work into context.
\end{abstract}

\section{INTRODUCTION}

Academic and popular interest in Japanese firms rose with the country's Gross Domestic Product (GDP) from the 1960s through the 1980s (Endo, Delbridge, \& Morris, 2015). Unfortunately, academic interest waned along with the economic decline associated with Japan's last 25 "lost years" (Keizer, 2011). Even in this environment management studies have continued to a degree and organizational behavior $(\mathrm{OB})$ related research has continued for the duration. Therefore, a monitoring of journal content is still necessary if we are to understand, which is not to say control, the nature and scope of OB research on Japan being published. This paper reports the status of Japanese-focused OB literature appearing between 2002 and 2015 to inform our understanding of the state of that research and to point us to future work. This data is compared to analysis appearing between 1981 and 2001 to answer four questions: (1) Has there been a relative increase in the proportion of Japanese-focused papers published; (2) Has there been a relative increase in the proportion of Japanese-focused OB papers published (3) What is the nature of Japanese-focused OB papers; and (4) Are there "gaps" in the Japanese-focused OB literature? Japanese management is not perfect (Keys, Denton, \& Miller, 1994), but there is much we can learn from their day-to-day practice.

\section{METHOD}

This study extends the prior work of Godkin, Endoh, and Cahill (1995) and Godkin, Doughty, and Hoosier (2003). That research surveyed journals selected from among 24 identified by Nancy Adler (1983) as "recognized to be the better journals in the field of management and OB" and/or which tended 
to "carry more international management papers" (p. 226). Twenty journals were selected from her list because they allowed for publication trends to emerge. The remainder experienced interruption (Godkin, Endoh, \& Cahill, 1995). The contents of the usable 20 journals were identified as follows.

\section{Identification of Papers}

Although this study is a replication of two prior studies (Godkin, Endoh, \& Cahill, 1995; Godkin, Doughty, \& Hoosier, 2003), much has improved in electronic access to library materials since those works were published. Therefore, this study deviated from the data bases used in their study. Because the purpose was to retrieve all papers published in the 20 journals considered in PDF format, this study relied primarily on Business Source Complete. This approach would accomplish the same aim. Where full text of individual papers were unavailable, other means were used including the searching of other databases and quarrying publishers' websites. The database supplied by the Academy of Management was utilized to isolate the Proceedings of the Annual Meeting.

The research process involved the printing of all tables of contents from the selected journals appearing between 2002 and 2015. A three-step process was used to find the required tables of contents including: (1) log on to the electronic data base; (2) click on Journals Search; (3) enter the title of the journal; (4) click on one or more of the links allowing online access to the dates between 2002 and 2015; (5) click on the individual years provided; and (6) click on and print the various volumes available; and (7) print the Tables of Contents.

The Tables of Contents were manually scrutinized to locate all papers containing the word "Japan" or "Japanese" in the title. To confirm all of those papers had been located, we performed the following steps: (1) clicked on the electronic data base; (2) clicked on Business Source Complete; (3) entered the journal title as "Source" and the word "Japan" as "Title" and repeated that process using the word "Japanese," and (4) papers appearing between 2002 and 2015 were aggregated and compared to the lists already in hand as described earlier. Letters from the editor, letters to the editor, briefings from the editor, dissertation abstracts, dissertation notes, book reviews, research notes, editorials of four or fewer pages, and brief reviews were eliminated from the sample. Only papers were included in the analysis.

\section{General Classification}

To undertake this study, Japanese-focused management papers were categorized as: (1) OB papers which analyzed the way(s) people behaved in organizations; (2) General Management papers which addressed management topics unrelated to $\mathrm{OB}$; (3) General Interest papers relating any papers falling outside the other two categories.

\section{Categorization of OB Papers}

OB papers identified were categorized as: (1) Domestic papers which focused on Japan; (2) Comparative papers which contrasted organizations in Japan with any other country or culture; (3) Intercultural papers which included $\mathrm{OB}$ papers centering on the interaction between organization members from Japan with any other country or culture. The prior studies (Godkin, Endoh, \& Cahill, 1995; Godkin, Doughty, \& Hoosier, 2003) upon which this replication is based borrowed from other researchers (Roberts,1970; Bhagat \& McQuaud, 1982; Keys \& Miller, 1984) to create these categories. Each Japanese-focused OB paper identified was categorized according to its primary focus using the scheme used in the earlier studies (Table 1). The papers were further categorized as empirical or topical replicating the earlier studies. Each paper was read to determine if culture was implicitly or explicitly present in each. As Adler noted (1983), "...the concept of culture did not mean that the researcher had claimed that culture was a significant variable. It simply meant that culture, as a variable or a construct, was not ignored" (p. 228). 


\title{
TABLE 1
}

RESEARCH CLASSIFICATION SCHEME FOR JAPAN-FOCUSED OB PAPERS

\author{
Level of Analysis
}

\begin{tabular}{|c|c|c|c|c|}
\hline Individual & Group & Organization & Social & Other \\
\hline $\begin{array}{ll}\text { - } & \text { Values \& } \\
& \text { attitudes } \\
\text { - } & \text { Personality } \\
\text { - } & \text { Perception } \\
\text { - } & \text { Motivation } \\
\text { - } & \text { Satisfaction, } \\
& \text { absence, \& } \\
\text { turnover }\end{array}$ & $\begin{array}{ll}\text { - } & \text { Quality Circles } \\
\text { - } & \text { Leadership } \\
\text { - } & \text { Communication } \\
\text { - } & \text { Group decision } \\
& \text { making }\end{array}$ & $\begin{array}{ll}\text { - Human resource } \\
\text { policies \& } \\
\text { practices } \\
\text { - } \\
\text { Organizational } \\
\text { structure } \\
\text { - } \\
\text { Organizational } \\
\text { culture } \\
\text { - } \\
\text { Efficiency \& } \\
\text { Productivity }\end{array}$ & $\begin{array}{l}\text { - National } \\
\text { culture }\end{array}$ & $\begin{array}{l}\text { Transferability } \\
\text { (adoptability } \\
\text { by foreign } \\
\text { nations) }\end{array}$ \\
\hline
\end{tabular}

\section{FINDINGS}

A total of 54,328 papers were contained in the journals between 1981-2015 and 35,484 papers appeared during the period 2002-2015 (Table 2). During 1981-1993 there were 11,837 (Godkin, Endoh, \& Cahill, 1995) and between 1994 and 2001 there were 7,017 (Godkin, Doughty, \& Hoosier, 2003). In this section, analysis of the most recent period juxtaposed with data from the prior periods is presented following the four research questions detailed earlier.

\section{TABLE 2}

\section{JAPAN-FOCUSED OB PAPERS CONTAINED IN SELECTED JOURNALS: 1981-2015}

\begin{tabular}{|c|c|c|c|c|c|c|c|c|c|c|}
\hline \multirow{2}{*}{ Journal } & \multicolumn{4}{|c|}{$\begin{array}{c}\text { 1981-1993 } \\
\text { (Godkin, Endoh, \& Cahill, } \\
\text { 1995) }\end{array}$} & \multicolumn{4}{|c|}{$\begin{array}{c}\text { 1994-2001 } \\
\text { (Godkin, Doughty, \& } \\
\text { Hoosier, 2003) }\end{array}$} & \multicolumn{2}{|r|}{$\begin{array}{r}2002-201 \\
\text { Current Stı }\end{array}$} \\
\hline & 䒕 & 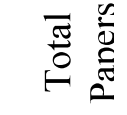 & & $\begin{array}{l}\text { an- } \\
\text { ised }\end{array}$ & $\begin{array}{l}\text { ज्ञ } \\
\stackrel{\Xi}{ \pm}\end{array}$ & $\begin{array}{lll}\pi & \\
0 & \end{array}$ & & $\begin{array}{l}\text { un- } \\
\text { used }\end{array}$ & 茂 & 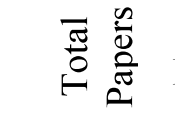 \\
\hline & & & $\mathrm{n}$ & $\%$ & & & $\mathrm{n}$ & $\%$ & & \\
\hline $\begin{array}{l}\text { Academy of Management } \\
\text { Journal }\end{array}$ & 16 & 570 & 4 & 0.007 & 9 & 443 & 8 & 1.805 & 9 & 966 \\
\hline $\begin{array}{l}\text { Academy of Management } \\
\text { Proceedings }\end{array}$ & 13 & 963 & 13 & 1.349 & 14 & 576 & 4 & 0.694 & 10 & 17,706 \\
\hline $\begin{array}{l}\text { Academy of Management } \\
\text { Review }\end{array}$ & 12 & 595 & 9 & 1.513 & 13 & 272 & 2 & 0.735 & 15 & 585 \\
\hline Across the Board & 10 & 1,197 & 35 & 2.924 & 16 & 438 & 0 & 0.000 & 11 & 1360 \\
\hline $\begin{array}{l}\text { Administrative Science } \\
\text { Quarterly }\end{array}$ & 11 & 311 & 5 & 1.608 & 12 & 197 & 2 & 1.015 & 15 & 257 \\
\hline
\end{tabular}




\begin{tabular}{|c|c|c|c|c|c|c|c|c|c|c|}
\hline $\begin{array}{l}\text { California Management } \\
\text { Review }\end{array}$ & 1 & 447 & 58 & 12.975 & 7 & 236 & 6 & 2.542 & 8 & 411 \\
\hline $\begin{array}{l}\text { Columbia Journal of World } \\
\text { Business }\end{array}$ & 3 & 524 & 44 & 8.397 & 5 & 218 & 8 & 3.669 & 15 & 563 \\
\hline $\begin{array}{l}\text { Group and Organization } \\
\text { Studies }\end{array}$ & 18 & 350 & 0 & 0.000 & 16 & 162 & 0 & 0.000 & 15 & 426 \\
\hline Harvard Business Review & 9 & 957 & 35 & 3.657 & 14 & 577 & 4 & 0.693 & 14 & 3954 \\
\hline $\begin{array}{l}\text { International Journal of } \\
\text { Intercultural Relations }\end{array}$ & 6 & 299 & 14 & 4.682 & 1 & 241 & 17 & 7.054 & 3 & 831 \\
\hline $\begin{array}{l}\text { Journal of Applied } \\
\text { Behavioral Science }\end{array}$ & 17 & 288 & 1 & 0.003 & 11 & 210 & 3 & 1.428 & 15 & 335 \\
\hline $\begin{array}{l}\text { Journal of Applied } \\
\text { Psychology }\end{array}$ & 17 & 1147 & 4 & 0.003 & 15 & 662 & 3 & 0.453 & 13 & 1397 \\
\hline $\begin{array}{l}\text { Journal of International } \\
\text { Business Studies }\end{array}$ & 4 & 382 & 28 & 7.330 & 2 & 282 & 19 & 6.737 & 2 & 809 \\
\hline $\begin{array}{l}\text { Journal of Management } \\
\text { Studies }\end{array}$ & 14 & 421 & 5 & 1.188 & 4 & 323 & 17 & 5.263 & 5 & 895 \\
\hline Journal of Social Psychology & 15 & 1200 & 12 & 1.000 & 8 & 508 & 10 & 1.968 & 7 & 668 \\
\hline $\begin{array}{l}\text { Management International } \\
\text { Review }\end{array}$ & 2 & 396 & 35 & 8.838 & 3 & 139 & 8 & 5.755 & 4 & 524 \\
\hline Management Science & 16 & 1148 & 8 & 0.007 & 15 & 949 & 5 & 0.526 & 11 & 2064 \\
\hline Organizational Dynamics & 5 & 269 & 15 & 5.576 & 16 & 180 & 0 & 0.000 & 1 & 354 \\
\hline $\begin{array}{l}\text { SAM Advanced } \\
\text { Management Journal }\end{array}$ & 8 & 369 & 14 & 3.794 & 10 & 164 & 3 & 1.724 & 6 & 341 \\
\hline Sloan Management Review & 7 & 354 & 14 & 3.955 & 6 & 230 & 8 & 3.478 & 15 & 1038 \\
\hline Totals & --- & 12,187 & 353 & 0.0298 & -- & 7,017 & 127 & 1.810 & --- & 35,484 \\
\hline
\end{tabular}

Has there been a relative increase in the proportion of Japanese-focused papers published?

It was determined that Japan-focused papers accounted for 145 or $0.41 \%$ of the 35,484 papers published between 2002 and 2015 compared to 353 or $0.0298 \%$ for $1981-1993$ and 127 or $1.81 \%$ for 1994-2001 (Table 2). Between 1981 and 2015, there were 54,328 papers published with 631 of those (1.16\%) Japan-focused. For the years 2002-2015, Organizational Dynamics ranked first in the percentage of Japan-focused papers published while Academy of Management Proceedings had the absolute largest number published followed by the Journal of International Business Studies and International Journal of Intercultural Relations. For the years 1981-2015, California Management Review ranked first in the percentage of Japan-focused papers published while California Management Review, Journal of International Business Studies, and Academy of Management Proceedings contained the highest number in that order.

Has there been a relative increase in the proportion of Japanese-focused OB papers published?

This study confirmed the assertion of Keizer (2011) that academic interest in Japan declined during the economic downturn or the "lost years." There were 227 Japan-focused OB papers published during 1981-2015. Just as Godkin, Endoh, and Cahill (1995) asserted that the "proportion of Japanese-focused OB papers published followed no apparent pattern" (p. 8) between 1981 and 1993, the same appears plausible for 2002-2015 and 1981-2015 (Table 3). For the duration, Domestic papers considering OB within Japanese organizations were found within $74(32.5 \%)$ of the Japanese related OB papers. Proportionally, $37.8 \%$ were Comparative contrasting Japanese management to that of another country and $29.51 \%$ were Intercultural dealing with the interactions between the Japanese and any other group(s). 


\begin{tabular}{|c|c|c|c|c|}
\hline \multicolumn{5}{|c|}{$\begin{array}{c}\text { TABLE } 3 \\
\text { JAPAN-FOCUSED OB PAPERS CONTAINED IN SELECTED JOURNALS } \\
\text { BY OB PERSPECTIVE: 1981-2015 }\end{array}$} \\
\hline & \multirow[b]{2}{*}{ Year } & \multicolumn{3}{|c|}{ OB Perspective } \\
\hline & & Domestic & Comparative & Intercultural \\
\hline \multirow{13}{*}{$\begin{array}{l}\text { Godkin, Endoh, \& Cahill, } \\
\text { 1995) }\end{array}$} & 1981 & 10 & 2 & 2 \\
\hline & 1982 & 6 & 2 & 0 \\
\hline & 1983 & 4 & 7 & 4 \\
\hline & 1984 & 7 & 3 & 2 \\
\hline & 1985 & 6 & 5 & 3 \\
\hline & 1986 & 1 & 4 & 2 \\
\hline & 1987 & 3 & 4 & 2 \\
\hline & 1988 & 4 & 2 & 1 \\
\hline & 1989 & 2 & 3 & 2 \\
\hline & 1990 & 2 & 3 & 2 \\
\hline & 1991 & 2 & 3 & 3 \\
\hline & 1992 & 3 & 5 & 1 \\
\hline & 1993 & 3 & 11 & 0 \\
\hline \multirow{8}{*}{$\begin{array}{l}\text { (Godkin, Doughty, \& } \\
\text { Hoosier, 2003) }\end{array}$} & 1994 & 0 & 2 & 4 \\
\hline & 1995 & 1 & 3 & 7 \\
\hline & 1996 & 0 & 1 & 2 \\
\hline & 1997 & 2 & 3 & 0 \\
\hline & 1998 & 2 & 4 & 2 \\
\hline & 1999 & 3 & 7 & 3 \\
\hline & 2000 & 0 & 0 & 1 \\
\hline & 2001 & 1 & 0 & 4 \\
\hline \multirow{15}{*}{ Current Study } & 2002 & 0 & 1 & 4 \\
\hline & 2003 & 0 & 0 & 3 \\
\hline & 2004 & 1 & 1 & 0 \\
\hline & 2005 & 2 & 1 & 0 \\
\hline & 2006 & 0 & 0 & 2 \\
\hline & 2007 & 0 & 1 & 1 \\
\hline & 2008 & 0 & 0 & 1 \\
\hline & 2009 & 1 & 2 & 4 \\
\hline & 2010 & 0 & 2 & 0 \\
\hline & 2011 & 2 & 1 & 0 \\
\hline & 2012 & 0 & 0 & 2 \\
\hline & 2013 & 0 & 2 & 1 \\
\hline & 2014 & 4 & 0 & 1 \\
\hline & 2015 & 2 & 1 & 1 \\
\hline & Totals & 74 & 86 & 67 \\
\hline
\end{tabular}




\section{What is the nature of Japanese-focused OB papers?}

For the duration 1981-2015 it is of interest to note that of the 277 Japanese-focused OB papers appearing between 1981-2015 about 55\% were empirical (Table 4). In the 2002-2015 set 69.5\% were empirical, $45.3 \%$ in the $1981-1993$ set were empirical, and $65.3 \%$ of the papers in the 1994-2001 were empirical.

\section{TABLE 4}

JAPAN-FOCUSED OB TOPICS BY EMPIRICAL AND ANECDOTAL NATURE: 1981-2015

\begin{tabular}{|c|c|c|c|c|c|c|}
\hline \multirow{2}{*}{ OB Topics } & \multicolumn{3}{|c|}{$\begin{array}{c}\text { 1981-1993 } \\
\text { (Godkin, Endoh, \& } \\
\text { Cahill, 1995) }\end{array}$} & \multicolumn{3}{|c|}{$\begin{array}{c}\text { 1994-2001 } \\
\text { (Godkin, Doughty, } \\
\text { \& Hoosier, 2003) }\end{array}$} \\
\hline & $\begin{array}{l}\bar{\pi} \\
\stackrel{0}{0}\end{array}$ & : & $\begin{array}{l}\frac{\pi}{0} \\
\stackrel{0}{0} \\
\stackrel{0}{Z} \\
\vdots\end{array}$ & 苞 & 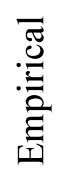 & 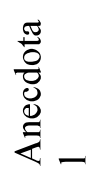 \\
\hline \multicolumn{7}{|l|}{ Individual Level } \\
\hline Values and Attitudes & 22 & 13 & 9 & 4 & 3 & 1 \\
\hline Personality & 0 & 0 & 0 & 4 & 4 & 0 \\
\hline Perception & 5 & 5 & 0 & 2 & 2 & 0 \\
\hline Motivation & 1 & 1 & 0 & 1 & 1 & 0 \\
\hline Satisfaction, Absences, Turnover & 2 & 2 & 0 & 1 & 2 & 0 \\
\hline \multicolumn{7}{|l|}{ Group Level } \\
\hline Quality Circles & 8 & 2 & 6 & 1 & 1 & 0 \\
\hline Leadership & 9 & 7 & 2 & 2 & 2 & 0 \\
\hline Communication & 8 & 5 & 3 & 7 & 5 & 2 \\
\hline Group decision making & 4 & 2 & 2 & 1 & 1 & 0 \\
\hline \multicolumn{7}{|l|}{ Organizational Level } \\
\hline Human resource policies $\&$ practices & 29 & 5 & 24 & 4 & 3 & 1 \\
\hline Organizational structure & 10 & 6 & 4 & 4 & 2 & 2 \\
\hline Organizational culture & 7 & 3 & 4 & 5 & 3 & 2 \\
\hline Efficiency \& Productivity & 10 & 3 & 7 & 3 & 2 & 1 \\
\hline \multicolumn{7}{|l|}{ Social Level } \\
\hline National Culture & 6 & 1 & 5 & 5 & 3 & 2 \\
\hline \multicolumn{7}{|l|}{ Other } \\
\hline Adoptability & 7 & 3 & 4 & 8 & 1 & 7 \\
\hline Totals & 128 & 58 & 70 & 52 & 34 & 18 \\
\hline
\end{tabular}

\section{Classification $1981-2015$}

The Japan-focused OB papers identified here were classified by level of analysis (Table 1) including the individual, group, organizational, and social levels as well as an "other" category. For the entire period, 1981 - 2015, the largest number of papers were related to the Organizational Level (91) of analysis where Human Resource Policies and Practices dominated (38) accompanyied by Organizational Structure, Organizational Culture, and Efficiency and Productivity. The second largest contained insights from the Group Level including Quality Circles, Leadership, Communication, and Group Decision Making. Following closely were papers dealing with topics on the Individual Level including Values and Attitudes, Personality, Perception, Motivation, and Satisfaction, Absences, and Turnover. The largest number of papers included the topics; (1) Human Resource Policies and Practices and (2) Values and Attitudes. 
This analysis extended the prior work for the most recent period $2002-2015$. The largest number of papers fell within the Organizational Level (19) followed by the Group Level (13) and the Individual Level (8). In terms of categorical focus, the largest number included Communication (9), Organization Structure (7), and National Culture (5).

Categorization $2002-2015$

Following earlier work (Godkin, Endoh, \& Cahill, 1995; Godkin, Doughty, \& Hoosier, 2003), the Japan-focused OB papers appearing between 2002 and 2015 were categorized as (1) Domestic papers which focused on Japan; (2) Comparative papers which contrasted organizations in Japan with any other country or culture; (3) Intercultural papers which included OB papers centering on the interaction between organization members from Japan with any other country or culture. The papers uncovered for this analysis were divergent, eclectic, and multifaceted in content. Therefore, this classification is used to present selected literature appearing between $2002-2015$.

\section{TABLE 5}

CATEGORICAL CLASSIFICATION OF JAPAN-FOCUSED OB PAPERS: 2002-2015

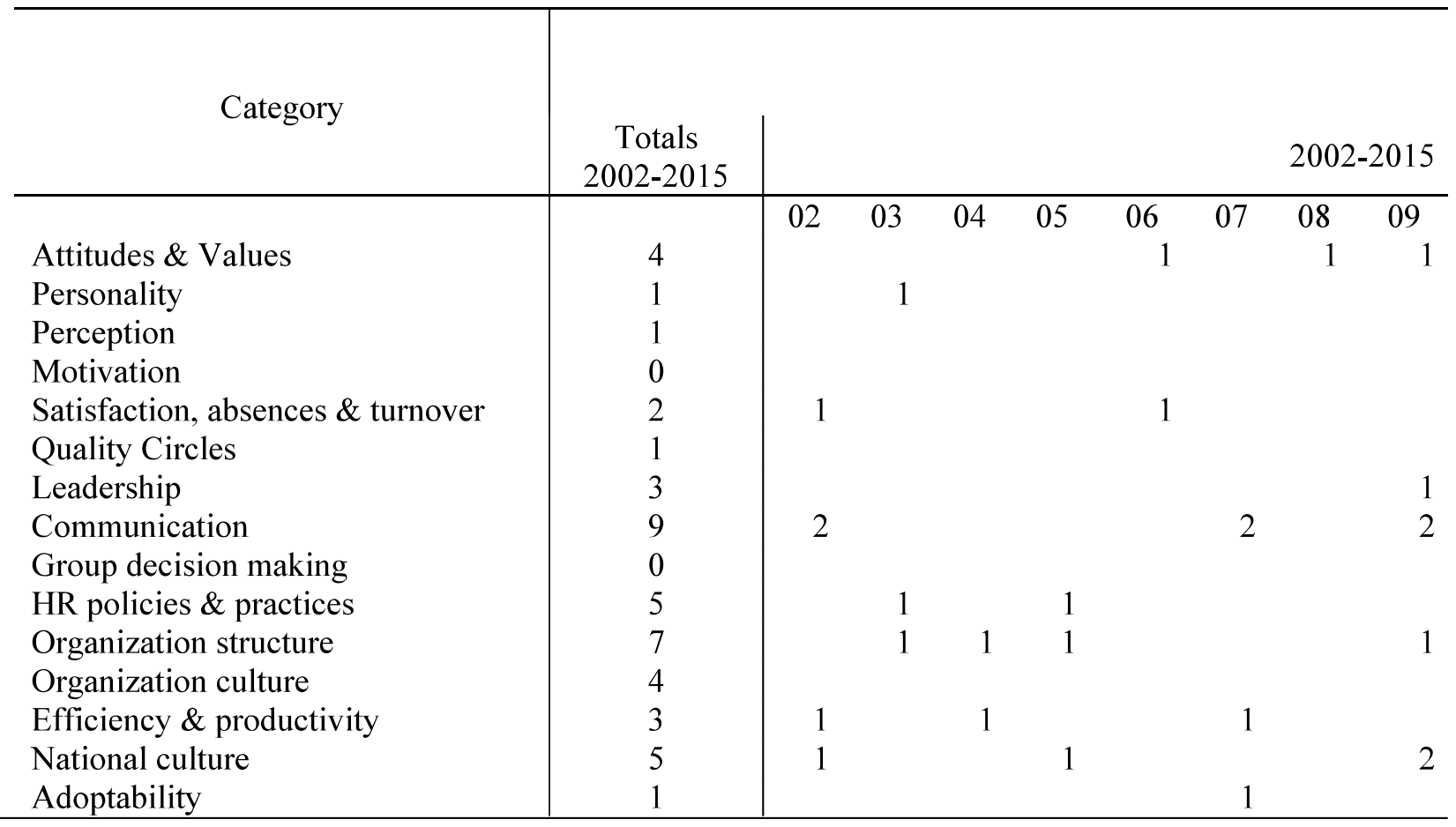

\section{Domestic Papers}

Domestic Japan-focused OB papers were a varied lot. A few examples will illustrate. For example, policy matters were raised. Chikudate (2002) suggested a "diagnostic theory" (p. 303) to explain aspects of systematic violations of the law by Japanese firms. Lehmberg (2014) detailed how Japanese human resource policies accounted for the misalignment of the country's economic and competitive environment. Internal consistency, self-reinforcing practices, cultural alignment, and institutionalization of work systems have limited the ability to change, adapt and work flexibly.

Organizational learning was front and center in a number of particular ways.

Kim, Lu, and Rhee (2012) focused on the experiential learning between and among foreign subsidiaries. Rooting their analysis in the organization evolution and organizational learning literatures, they report empirical evidence that the chances of survival for Japanese firms with different sister subsidiary entry cohorts is better because such situations provide non-redundant, complementary 
experiences. The learning is richer. Qualitative evidence supports the notion that multichannel experiences among sister subsidiaries is also beneficial. Temporal heterogeneity in the internationalization process is significant to multinational company learning. Olcott and Oliver (2014) describe how networks of Japanese companies have recovered and restored production following disaster. It demonstrates how networks of such firms mobilized and deployed resources to do so. They explain using social capital theory and sensemaking theory how shared mental models facilitated rapid mobilization and coordination of shared assistance under complex circumstances. Takeuchi, Lepak, Wang, and Takeuchi (2007) looked at high-performance work systems from the resource-based view of the firm and social exchange perspectives. Based on the analysis of a sample of Japanese firms, the authors report that high-performance work systems "...were found to be positively associated with the level of collective human capital in an organization, as well as with the degree of social exchange employees collectively perceive. These, in turn, have been related to relative establishment performance" (p. 1079).

Career progress and individual learning was also a point of interest to researchers. Concerning career trajectories, Graen, Dharwadhar, Grewal, and Wakabayashi (2006) longitudinally followed Japanese workers in a multinational firm. They determined that their "one-stage model of career progress" was as predictive as other models tested operating individually or in combination. They concluded that career progress in the high growth period experienced in Japan in the 1970's and 1980's was perhaps more complex than revealed by the two-stage career progress model previously popular. To understand effective individual learning of global management skills, Furuya, Stevens, Bird, Oddou, and Mendenhall (2009) considered the experience of 305 Japanese repatriates. They found organizational support, intercultural personality characteristics, self-adjustment, and repatriation policies linked to outcomes of global competency learning and transfer which resulted in improved job motivation and performance.

Finally, Sakuragi (2008) replicated a prior published study of intercultural communication. Contrary to the prior study, this survey of 116 Japanese students did not reveal a positive relationship between a general attitude toward language study and a cross-cultural attitude. Sakuragi's (2008) findings were consistent with the prior study. Motives for language study were correlated with social distance. There was also a relationship between attitudes toward specific languages and social distance.

\section{Intercultural Papers}

OB papers, entertaining the interaction between organization members from Japan with any other country or culture (e.g., Godkin, Endoh, \& Cahill, 1995; Godkin, Doughty, \& Hoosier, 2003), instruct us about the nature and scope of the literature isolated here. Several researchers investigated the expatriate experience. For example, Greenland and Brown (2005) incorporated acculturation theory and the general intergroup literature to understand the behavior of Japanese nationals working the United Kingdom over a period of 12 months. They found that intergroup anxiety resulted in increased acculturative stress and pscyhosomatic illness was associated with in-group bias.

Takeuchi, Lepak, Marinova, and Yun (2007) studied the relationships between parental demands, learning, and expatriate adjustment among 170 matched pairs of Japanese expatriates and spouses assigned to the U.S. They found a quadratic effect of parental demands and a cubic effect of cultural novelty on general spousal adjustment, but not on the general expatriate adjustment. They surmised this result may be related to strong gender roles. Yoshida, Matsumoto, Akashi, Akiyama, Furuiye, Ishii, and Moriyoshi (2009) sought to determine what separated Japanese expatriate returnees who had more adjustment difficulties from those who had fewer. Both groups experienced stereotyping of themselves. In contrast, those who had fewer problems believed there were more people who accepted them as they were when they first returned to Japan. Those who had more problems felt fewer people accepted them for who they were and they also reported being overtly bullied and felt they experienced greater levels of discrimination.

Researchers also directed some attention to the experience of students accompanying Japanese expatriate parents on international assignments. Yoshida, Matsumoto, Akiyama, Moriyoshi, Furuiye, Ishii, and Franklin (2002) tested 27 psychological and social outcomes of Japanese children of parents 
working abroad. Factor analysis revealed communication with parents, recency of return, and special provisions for students were significant to having a positive experience. Alternatively, Toyokawa and Toyokawa (2002) looked at 84 Japanese students studying in the US over a 10-month period. They compared the students' participation in extracurricular activities with their ability to adjust to American campus life. They found that engagement in extracurricular activities positively related to general satisfaction with their lives, increased benefits to their academic studies and extracurricular activities, and higher involvement in their academic studies in general.

Sasagawa, Toyoda, and Sakano (2006) compared Japanese students who returned from abroad $(\mathrm{N}=$ 141) with those who had never lived outside of Japan $(\mathrm{N}=148)$ on the basis of individualismcollectivism (I-C) and locus of control (LOC). Those who traveled abroad were divided into two groups; those exposed to an individualistic/internal-LOC oriented country (i/I group) or a collectivistic/externalLOC oriented country (c/e group). Those who did not leave Japan completed questionnaires containing both I-C and LOC measures. The c/e group was more individualistic than those in the i/I group. It was suggested that Japanese returning from abroad may be well aware of public attitudes toward them.

Expatriates assigned to management with higher organizational roles was the focus of work by Belderbos and Heijltjes (2005). They concerned themselves with what determined the decision to appoint expatriates to the managing director position at overseas affiliates. They used a sample of 844 Japanese manufacturing affiliates operating in Asia in 1995. They determined that dependence on the parent affiliate increased the tendency to appoint expatriates. Where affiliates were localized, there was a lower tendency to do so. Expanded local experience by both the firm and the affiliate increased the probability that host country nationals would be appointed to those positions.

Job satisfaction was of interest to Yamaguchi (2013) who explored the relationships between team autonomy, organizational social capital, and worker attitudes of job satisfaction and organizational commitment. Surveys were distributed to Japanese $(n=532)$ and US $(n=536)$ workers Team autonomy was not related to structural social capital (i.e., density of work) for Japanese workers, but was related for American workers. There was a stronger negative relationship between structural social capital and job satisfaction among the Japanese than the American workers. There was no difference that the mediating effects of relational/cognitive social capital (i.e., trust) had on autonomy and both job satisfaction and organizational commitment for either the Japanese or the Americans.

Loess and Yavas (2003), using a survey and follow-up interviews, analyzed Japanese/US joint ventures in the auto supply. They concluded that collaborative attitudes were strongest when not filtered through participants' joint venture tasks and responsibilities. Interaction variables were strongest in situations where basic communication has been previously established.

Intercultural communication was considered in the context of negotiations between American and Japanese and attitudes toward language study among Japanese. Adair, Weingart, and Brett (2007) examined the function of offers in US and Japanese integrative negotiations using the transcripts of 20 US and 20 Japanese dyads. Early offers resulted in higher joint gains for Japanese negotiators and lower ones for US negotiators. Early offers represented information gathering in Japanese negotiations and information consolidation in US negotiations.

In light of the "graying" of Japan, Komisarof (2009) questioned the efficacy of incorporating more non-Japanese into the Japanese workforce. The investigation assessed how the acculturation strategy compatibility between Japanese and American coworkers affected the quality of their intercultural relations using the Interactive Acculturation Model (IAM). Conflictual IAM types often scored lower on dependent measures and Consensual or Problematic IAM types. Consensual IAM types and Problematic IAM types did not differ in their scores on any of the dependent variables.

\section{Are there "gaps" in the Japanese-focused OB literature?}

For researchers seeking insight into Japan-focused OB, it might be said that what has not been covered can be as informative as what has been covered in related literature. In the period 1981-2015 a number of topics have represented "gaps" in the literature. For example. papers addressing Personality, Motivation; Satisfaction, Absences, and Turnover, and Group decision-making were nonexistent or few 
in number in the 1981-1992 collection of papers (Godkin, Endoh, \& Cahill, 1995). Coverage of Personality, overlooked in the prior time period, was addressed in three papers between 1994 and 2001 (Godkin, Doughty, \& Hoosier, 2003). For the duration (1981-2015), there were no Japan-focused OB papers related to Motivation or Group Decision Making (Table 5).

\section{CONCLUSIONS}

The current set of journals may not be representative of the literature in monitoring Japanese-focused OB publication going forward. However, using a consistent set of academic management journals for the duration of the study, this paper reports a content analysis of a consistent set of academic management journals covering Japanese-focused OB over a period of 35 years. The purpose of this paper was to answer four basic questions concerning the Japan-focused OB publication appearing in a selected pool of journals between 1985 and 2015: (1) Has there been a relative increase in the proportion of Japanesefocused papers published; (2) Has there been a relative increase in the proportion of Japanese-focused OB papers published; (3) What is the nature of Japanese-focused OB papers; and (4) Are there "gaps" in the Japanese-focused OB literature? The following conclusions can be drawn.

First, over the 35 years of publication considered here, 54,328 papers were published with 35,484 or $65 \%$ of those appearing between 2002 and 2015 . Of the $54,328,631$ or $1.16 \%$ focused on Japan with 227 relating to Japan OB in particular. This is a relatively small number, but it does indicate that Japan is still on the academic radar and OB papers focusing on Japan are still being produced. Of the Japan-focused OB papers appearing throughout the duration, 74 were Domestic considering only Japan; 86 were Comparative contrasting organizations in Japan with any other country or culture; and 67 were Intercultural centering on the interaction between organization members from Japan with those from other countries or cultures.

Second, there has not been a discernable increase in the proportion of Japan-focused papers published annually since 1981. Unfortunately, the academic interest that waned along with the economic decline associated with Japan's "lost years" (Keizer, 2011) may have continued through 2015. The proportion of Japanese-focused OB papers seems to have followed a similar trajectory.

Third, a number of OB topics have dominated the Japanese-focused literature while others have been comparatively absent. For example, between 1981 and 2015 at total of 38 or $16.7 \%$ related to Human Resource Policies and Practices while 30 or $13.2 \%$ were related to Values and Attitudes. Alternatively, only 2 papers or $0.008 \%$ were published about Perception while (1) Personality, (2) Satisfaction, Absences, Turnover, and Group Decision Making were represented by 5 or $0.022 \%$ each.

Fourth, between 1981 and 2015, about 55\% of the Japan-focused OB papers were empirical. For the period 1981-1993, a total of $45.3 \%$ were empirical; the interval 1994-2001, 65.3\% were empirical; and for the segment 2002-2015, 69.5\% were empirical.

Fifth, over the entire period (1981-2015) no Japan-focused OB papers related to Motivation or Group Decision Making appeared (Table 5).

"Japan is like an oyster. An oyster dislikes foreign objects: When even the smallest grain of sand or broken shell finds its way inside the oyster shell, the oyster finds the invasion intolerable, so it secretes layer after layer of nacre upon the surface of the offending particle, eventually creating a beautiful pearl (Kerr, 1996, p. 231 cited in Štrach \& Everett, 2004). Yet, the nature of academic publication is changing rapidly. Periodic content analysis related to various areas of study, along with in depth reviews of the literature, remain important. There is no doubt, going forward, that some of the journals covered in this study will be altered by their editors or they will simply cease publication. More effective ways to monitor, which is not to say control, the nature and scope of Japanese-focused OB research need to be designed. 


\section{REFERENCES}

Adair, W. L., Weingart, L., and Brett, J. (2007). "The timing and function of offers in the U.S. and Japanese negotiations", Journal of Applied Psychology, Vol. 92 No. 4, pp. 1056-1068. DOI: 10.1037/0021-9010.92.4.1056

Adler, N. (1983). "Cross-cultural management research: the Ostrich and the trend", Academy of Management Review, Vol. 8 No. 2, pp. 226-232. DOI: 10.5465/AMR.1983.4284725

Belderbos, R. A. and Heijltjes, M. G. (2005). "The determinants of expatriate staffing by Japanese multinationals in Asia: control, learning and vertical business groups", Journal of International Business Studies, Vol. 36 No. 3, pp. 341-354. DOI: 10.1057/palgrave.jibs.8400135

Bhagat, R. S. and McQuaud, S. J. (1982). "Role of subjective culture in organizations: a review and directions for future research", Journal of Applied Psychology Monograph, Vol. 67 No. 5, pp. 653-685.

Chikudate, N. (2002). "Collective myopia and disciplinary power behind the scenes of unethical practices: a diagnostic theory on Japanese organization", Journal of Management Studies, Vol. 39 No. 3, pp. 289-307.

Endo, T., Delbridge, R., and Morris, J. (2015). "Does Japan still matter? Past tendencies and future opportunities in the study of Japanese firms", International Journal of Management Reviews, Vol. 17 No. 1, pp.101-123. DOI: 10.1111/ijmr.12039

Furuya, N., Stevens, M. J., Bird, A., Oddou, G., and Mendenhall, M. (2009). "Managing the learning and transfer of global management competence: antecedents and outcomes of Japanese repatriation effectiveness", Journal of International Business Studies, Vol. 40 No. 2, pp. 200-215. DOI: 10.1057/palgrave.jibs. 8400416

Godkin, L., Endoh, M., and Cahill, M. (1995). "Japanese-focused organizational behavior research: contents and concerns 1981-1993”, International Journal of Organizational Analysis, Vol. 3 No. 4, pp. 5-19.

Godkin, L., Doughty, G., and Hoosier, B. (2003). "Japanese-focused organizational behavior research 1981-2001: content and comment”. International Journal of Organizational Analysis, Vol. 11 No. 4, pp. 303-318.

Graen, G., Dharwadhar, R., Grewal, R., and Wakabayashi, M. (2006). "Japanese career progress: an empirical examination”, Journal of International Business Studies, Vol. 37, pp.148-161. DOI: 10.1057/palgrave.jibs.8400175

Greenland, K. and Brown, R. (2005). "Acculturation and contact in Japanese students studying in the United Kingdom”, The Journal of Social Psychology, Vol. 145 No. 4, pp. 373-389. DOI:10.3200/SOCP.145.4.373-390

Keizer, A.B. (2011). "Flexibility in Japanese internal labour markets: the introduction of performance related pay", Asia Pacific Journal of Management, Vol. 28 No. 3, pp. 573- 594. DOI: 10.1007/s10490-009-9170-3

Kerr, A. (1996). Lost Japan. Hawthorn. Victoria. Australia: Lonely Planet Publications.

Keys, J. B., Denton, L. T., and Miller, T. R. (1994). "The Japanese management theory jungle Revisited", Journal of Management, Vol. 20 No. 2, pp. 373-402. DOI:10.1177/014920639402000205

Keys, J. B. and Miller, T. R. (1984). "The Japanese management theory-jungle", Academy of Management Review, Vol. 9 No. 2, pp. 342-353. DOI: 10.5465/AMR.1984.4277677

Kim, Y-C., Lu, J. W., and Rhee, M. (2012). "Learning from age difference: interorganizational learning and survival in Japanese foreign subsidiaries. Journal of International Business Studies, Vol. 43 No. 8, pp. 719-745.

Komisarof, A. (2009). "Testing a modified interactive acculturation model in Japan: American-Japanese coworker relations", International Journal of Intercultural Relations, Vol. 33 No. 5, pp. 399-418. DOI: $10.1016 /$ j.ijintrel.2009.03.007

Lehmberg, D. (2014). "From advantage to handicap: traditional Japanese HRM and the case for Change", Organizational Dynamics, Vol. 43 No. 2, pp. 146-153. DOI: 10.1016/j.orgdyn.2014.03.009 
Loess, K. H. and Yavas, U. (2003). "Human resource collaboration issues in international joint ventures: a study of US-Japanese auto supply IJVs", Management International Review, Vol. 43 No. 3, pp. 311-327.

Olcott, G. and Oliver, N. (2014). "Social capital, sensemaking, and recovery: Japanese companies and the 2011 earthquake", California Management Review, Vol. 56 No. 2, pp. 5-22.

Roberts, K. H. (1970). "On looking at an elephant: an evaluation of cross-cultural research related to organizations", Psychology Bulletin, Vol. 74 No. 5, pp. 327-350. DOI: 10.1037/h0030140

Sakuragi, T. (2008). "Attitudes toward language study and cross-cultural attitudes in Japan", International Journal of intercultural Relations, Vol. 32 No. 1, pp. 81-90. DOI:10.1016/j.ijintrel.2007.10.005

Sasagawa, S., Toyoda, H., and Sakano, Y. (2006). "The acquisition of cultural values in Japanese returnee students", International Journal of Intercultural Relations, Vol. 30 No. 3, pp. 333-343. DOI: 10.1016/j.ijintrel.2005.08.005

Strach, P. and Everett, A. M. (2004). "Is there anything left to learn from Japanese companies?",SAM Advanced Management Journal, Vol.. 69 No. 3, pp. 4-13.

Takeuchi, R., Lepak, D. P., Marinova, S. V., and Yun, S. (2007). Nonlinear influences of stressors on general adjustment: the case of Japanese expatriates and their spouses", Journal of International Business Studies, Vol. 38, pp. 928-943. DOI: 0.1057/palgrave.jibs.8400298

Takeuchi, R., Lepak, D. P., Wang, H., and Takeuchi, K. (2007). "An empirical examination of the mechanisms mediating between high-performance work systems and the performance of Japanese organizations", Journal of Applied Psychology, Vol. 92 No. 4, pp. 1069-1083.

Toyokawa, T. and Toyokawa, N. (2002). "Extracurricular activities and the adjustment of Asian international students: a study of Japanese students", International Journal of Intercultural Relations, Vol. 26, pp. 363-379.

Yamaguchi, I. (2013). "A Japan-US cross-cultural study of relationships among team autonomy, organizational social capital, job satisfaction, and organizational commitment", International Journal of Intercultural Relations, Vol. 37, pp. 58-71. DOI: 10.1016/j.ijintrel.2012.04.016

Yoshida, T., Matsumoto, D., Akashi, S., Akiyama, T., Furuiye, A., Ishii, C., and Moriyoshi, N. (2009). "Contrasting experiences in Japanese returnee adjustment: those who adjust easily and those who do not", International Journal of Intercultural Relations, Vol. 33 No. 4, pp. 265-276. DOI: 10.1016/j.ijintrel.2009.04.003

Yoshida, T., Matsumoto, D., Akiyama, T., Moriyoshi, N., Furuiye, A., Ishii, C., and Franklin, B. (2002). "The Japanese returnee experience: factors that affect reentry", International Journal of Intercultural Relations, Vol. 26 No. 4, pp. 429-445. DOI:10.1016/S0147-1767(02)00015-9 